\title{
Losartan reduces trinitrobenzene sulphonic acid-induced colorectal fibrosis in rats
}

\author{
Dov Wengrower $\mathrm{MD}^{1 *}$, Giuliana Zanninelli $M \mathrm{PD}^{2}{ }^{2}$, Giovanni Latella $\mathrm{MD}^{2}$, Stefano Necozione $\mathrm{MD}^{3}$,

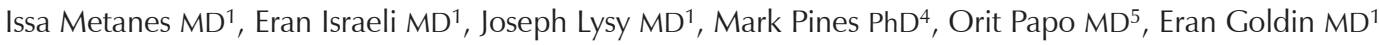

D Wengrower, G Zanninelli, G Latella, et al. Losartan reduces trinitrobenzene sulphonic acid-induced colorectal fibrosis in rats. Can J Gastroenterol 2012;26(1):33-39.

BACKGROUND: Intestinal fibrosis is a challenging clinical condition in several fibrostenosing enteropathies, particularly Crohn's disease. Currently, no effective preventive measures or medical therapies are available for intestinal fibrosis. Fibrosis, due to an abnormal accumulation of extracellular matrix proteins, is a chronic and progressive process mediated by cell/matrix/cytokine and growth factor interactions, but may be a reversible phenomenon. Of the several molecules regulating fibrogenesis, transforming growth factor-beta 1 (TGF- $\beta 1$ ) appears to play a pivotal role; it is strongly induced by the local activation of angiotensin II. The levels of both TGF- $\beta 1$ and angiotensin II are elevated in fibrostenosing Crohn's disease.

AIMS: To evaluate the in vivo effect of losartan - an angiotensin II receptor antagonist - on the course of chronic colitis-associated fibrosis and on TGF- $\beta 1$ expression.

METHODS: Colitis was induced by intrarectal instillation of trinitrobenzene sulphonic acid (TNBS) $(15 \mathrm{mg} / \mathrm{mL})$ while losartan was administered orally daily by gavage $(7 \mathrm{mg} / \mathrm{kg} /$ day $)$ for 21 days. Three groups of rats were evaluated: control $(n=10)$; TNBS treated $(n=10)$; and TNBS + losartan treated $(n=10)$. Inflammation and fibrosis of the colon were evaluated by macro- and microscopic score analysis. Colonic TGF- $\beta 1$ levels was measured using ELISA.

RESULTS: Twenty-one days after induction, losartan significantly improved the macro- and microscopic scores of fibrosis in the colonic wall and reduced TGF- $\beta 1$ concentration.

CONCLUSIONS: Prophylactic oral administration of losartan reduces the colorectal fibrosis complicating the TNBS-induced chronic colitis, an effect that appears to be mediated by a downregulation of TGF- $\beta 1$ expression.

Key Words: Angiotensin II receptor antagonist; Experimental colitis; Fibrosis; Inflammatory bowel disease; Losartan; TGF- $\beta 1$; TNBS

\section{Le losartan réduit la fibrose colorectale induite par l'acide sulfonique de trinitrobenzène chez les rats}

HISTORIQUE : La fibrose intestinale est un problème clinique complexe dans plusieurs entéropathies fibrosténosantes, notamment la maladie de Crohn. Il n'existe pas de mesure préventive ou de médicothérapie efficaces pour traiter la fibrose intestinale. La fibrose, causée par l'accumulation anormale de protéines de la matrice extracellulaire, est un processus chronique évolutif médié par les interactions des cellules, de la matrice et de la cytokine avec le facteur de croissance, mais pourrait être un phénomène réversible. Parmi les quelques molécules qui régularisent la fibrogenèse, le facteur de croissance transformant bêta 1 (FCT- $\beta 1$ ) semble jouer un rôle essentiel, fortement induit par l'activation locale de l'angiotensine II. Les taux de FCT- $\beta 1$ et d'angiotensine. II sont élevés en cas de maladie de Crohn fibrosténosante.

OBJECTIF : Évaluer l'effet in vivo du losartan - un antagoniste des récepteurs de l'angiotensine II - sur l'évolution de la fibrose associée à la colite chronique et sur l'expression du FCT- $\beta 1$.

MÉTHODOLOGIE : La colite était induite par l'instillation intrarectale d'acidesulphonique de trinitrobenzène (ASTB) $(15 \mathrm{mg} / \mathrm{mL})$, tandis que le losartanétait administré tous les jours par gavage oral $(7 \mathrm{mg} / \mathrm{kg} /$ jour $)$ pendant 21 jours. Les chercheurs ont évalué trois groupes de rats : les rats témoins $(n=10)$, les rats traités par ASTB $(n=10)$ et les rats traités par ASTB et losartan $(n=10)$. Ils ont évalué l'inflammation et la fibrose du côlon au moyen d'une analyse des indices macroscopique et microscopique et mesuré les taux de FCT- $\beta 1$ au moyen d'ELISA.

RÉSULTATS : Vingt et un jours après l'induction, le losartan améliorait considérablement les indices macroscopique et microscopique de fibrose dans la paroi du côlon et réduisait la concentration du FCT- $\beta 1$.

CONCLUSIONS : L'administration de losartan prophylactique par voie orale réduit la fibrose colorectale qui complique la colite chronique induite par l'ASTB, un effet qui semble médié par une sousrégulation de l'expression du FCT- $\beta 1$.

\begin{abstract}
Intestinal fibrosis, which may lead to stenosis and obstruction, may develop in several enteropathies including inflammatory bowel disease (IBD), radiation enteropathy, graft versus host disease, collagenous colitis, eosinophilic enteropathy, drug-induced enteropathy and postsurgical intestinal adhesions and stenosis (1-4). The most frequent and severe intestinal fibrosis occurs in patients with Crohn's disease (CD), which invariably recurs after surgical intestinal resection $(5,6)$. Despite advances in CD management over the past two decades, the incidence of strictures and the requirement for intestinal resection have not diminished (7). Currently, no effective preventive measures or medical therapies are available for intestinal fibrosis and, thus, surgery remains the only available antifibrotic strategy in the management of fibrostenosing CD (3).
\end{abstract}

Intestinal strictures characteristically display thickening of all layers of the intestinal wall. Histological examination shows the presence of abnormal collagen deposition that disorganizes the submucosa, muscularis mucosa, muscularis propria and serosal layers $(1,5)$. Collagen is one of the major component proteins of the extracellular matrix (ECM); several subtypes have been identified. Intestinal strictures are characterized by an increase in total collagen and also in the relative amount of type III collagen $(8,9)$.

While the pathogenesis of intestinal inflammation in IBD has been extensively investigated, knowledge of the pathogenesis of fibrosis remains limited.

Intestinal fibrosis, as it occurs in other organs, develops following chronic inflammation, but may progress independently of inflammation

${ }^{1}$ Institute of Gastroenterology, Hadassah University Hospital, Jerusalem, Israel; ${ }^{2}$ Gastroenterology Unit; ${ }^{3}$ Clinical Epidemiology Unit, Department of

Internal Medicine and Public Health, University of L'Aquila, L'Aquila, Italy; ${ }^{4}$ Institute of Animal Science, The Volcani Center, Bet Dagan;

${ }^{5}$ Department of Pathology, Hadassah University Hospital, Jerusalem, Israel. *Contributed equally to this work

Correspondence: Dr Dov Wengrower, Institute of Gastroenterology, Hadassah University Hospital, Hebrew University, PO Box 12000-Kyriat Hadassah,

Jerusalem 91120, Israel. Telephone 972-2-6678417, fax 972-2-6437492, e-mail dovw@ekmd.huji.ac.il

Received for publication March 5, 2011. Accepted March 25, 2011 
$(4,10-13)$. Fibrosis is a chronic and progressive process mediated by cell/ECM/cytokine and growth factor interactions; however, it may be a reversible phenomenon $(4,14,15)$. The physiological fibrogenesis process triggered by the onset of inflammation may lead to tissue repair or to fibrosis depending on the balance between ECM synthesis and degradation $(4,12)$. Intestinal fibrosis is related to abnormal accumulation of ECM proteins due to their increased production by activated intestinal mesenchymal cells, or to their reduced enzymatic degradation (4,10-12). ECM degradation is mediated by the matrix metalloproteinases (MMPs) and tissue inhibitors of MMPs $(4,12)$. As a consequence of chronic tissue damage, ECM-producing cells, especially fibroblasts and subepithelial myofibroblasts, undergo a process of activation characterized by proliferation, differentiation, motility, contractility and synthesis of ECM proteins.

The activation of ECM-producing cells is regulated by several soluble factors including cytokines, chemokines, growth factors and products of oxidative stress $(4,10-12)$. Of the molecules regulating the activation of ECM-producing cells, transforming growth factor-beta (TGF- $\beta$ ) appears to play a pivotal role $(4,16)$. TGF- $\beta$ is a member of a large family of pleiotropic cytokines that include bone morphogenetic proteins, activins and other related factors.

Three different isoforms of TGF- $\beta$ ( $\beta 1, \beta 2$ and $\beta 3)$ have been found in mammals, with TGF- $\beta 1$ being the most extensively studied. The TGF- $\beta$ intracellular signal transduction pathway is mediated mainly by Smad proteins (17-19). Aside from its central role in tissue fibrogenesis, TGF- $\beta /$ Smad signalling is clearly also involved in the control of organogenesis, oncogenesis, and immunoregulation and inflammation processes $(4,10-12,20)$. The concomitant and different roles of TGF- $\beta$, both in inflammation and fibrogenesis, appears to be mediated by its different intracellular transduction pathways (Smad dependent and independent) $(13,14,18-21)$.

TGF- $\beta /$ Smad signalling plays a central role in tissue fibrogenesis, acting as a potent stimulus of ECM protein accumulation. The expression of TGF- $\beta$ and its cell receptors is increased in intestinal fibrostenotic tissue and in the fibroblasts of the affected segments (16,22-25). Animal models of IBD provide additional compelling evidence for the fundamental role of TGF- $\beta$ in triggering and sustaining intestinal fibrogenesis (21,26-28). In particular, TGF- $\beta$ stimulates the production of the ECM and suppresses matrix degradation by inhibiting MMPs, thereby enhancing the deposition of collagen and other components of the $\operatorname{ECM}(4,5,10-12,29)$. Furthermore, TGF- $\beta 1$ provides a strong stimulus for the synthesis of connective tissue growth factor (CTGF), a potent stimulator of fibroblast and myofibroblast proliferation, ECM production and for the autoinduction of TGF- $\beta$ $(13,19,30,31)$. TGF- $\beta$ autoinduction is believed to be an important aspect in the maintenance of the fibrotic process over time (13). All of these responses to TGF- $\beta$ contribute to the onset and maintenance of fibrosis in the target organs.

The production of TGF- $\beta 1$ is strongly stimulated by the local activation of angiotensin (ANG) II (ANGII) (32-38), which is the principal effector of the renin-angiotensin system (RAS), the activity of which is increased in the colonic mucosa of CD patients (39). The role of the ANG cascade in the development of fibrosis has been widely described in different organs including kidney, heart, blood vessels, lung, pancreas and liver. It has been reported that the fibrogenic response to injury is strongly mediated through ANGII induction of TGF- $\beta 1$ expression (3438). Furthemore, fibrosis is significantly improved or even reversed by ANGII blockade by an angiotensin-converting enzyme (ACE) inhibitor or ANGII receptor antagonist: findings that are closely correlated to the reduction of TGF- $\beta 1$ expression (40-54). These observations suggested that the neutralization of the fibrogenic ANGII could also be a beneficial therapeutic target in intestinal fibrosis. To test this hypothesis, we previously evaluated the efficacy of inhibition of ANGII by captopril, an ACE inhibitor, in the prevention of trinitrobenzene sulphonic acid (TNBS)-induced chronic colitis-associated fibrosis. For the first time, we demonstrated that captopril was effective in preventing colorectal fibrosis in 2,4,6-TNBS-induced chronic colitis, and showed that antifibrotic action was mediated by a downregulation of TGF- $\beta 1$ overexpression (27).

Based on these data, we hypothesized that experimental colorectal fibrosis could be also prevented by administration of losartan - a specific ANGII receptor antagonist. In the present study, we evaluated the effects of losartan on the course of TNBS-induced chronic colitis with colorectal fibrosis, and on colonic TGF- $\beta 1$ expression in rats. This experimental model of colitis resembles human CD with transmural lesions and serosal involvement. Intestinal lesions are observed from one to three weeks after intrarectal administration of TNBS.

\section{METHODS}

\section{Materials}

Losartan was purchased from Hadassah Pharmacy (Jerusalem, Israel), as Cozaar (Merck Sharpe \& Dohme, Isreal) (losartan potassium). All other reagents were purchased from Sigma Chemical Co (USA) unless otherwise indicated. 2,4,6-TNBS was purchased from Sigma Chemical Co (USA).

\section{Animals}

Thirty healthy male Sabra rats weighing $300 \mathrm{~g}$ to $325 \mathrm{~g}$ were used (Harlan Jerusalem, Israel). The animals were kept in a restrictedaccess room with controlled temperature $\left(23^{\circ} \mathrm{C}\right)$ and $12 \mathrm{~h} \mathrm{light} / 12 \mathrm{~h}$ dark cycles. Standard rodent chow and tap water was allowed ad libitum. The Animal Research Committee of Hadassah School of Medicine and the Hebrew University (Jerusalem, Israel) approved the protocol.

\section{Induction of colitis}

Under light ether anesthesia, colitis was induced by intrarectal instillation of TNBS $(15 \mathrm{mg} / \mathrm{mL})$ diluted in an equal volume of $50 \%$ ethanol (volume/volume) as described by Morris et al (55). The animals were deprived of food for $24 \mathrm{~h}$ before TNBS instillation. The solution of TNBS-ethanol was administered in a total volume of $1 \mathrm{~mL}$ through medical-grade, polyurethane 6 Fr enteral feeding tubes, the tips of which were positioned at $8 \mathrm{~cm}$ past the anus. The cannula was left in place for $1 \mathrm{~min}$ to ensure that the TNBS-solution would not be expelled immediately. Animals in the control groups were given an enema of the same volume containing $0.9 \%$ saline instead of TNBS.

Animals were observed daily for food and fluid intake. The rats were weighed before TNBS administration and on the day they were sacrificed. Major signs of colitis including body weight loss, diarrhea and hematochezia were evaluated and scored at 21 days after TNBS instillation. The severity of diarrhea was assessed according to a scale from 0 to $3(0=$ no diarrhea; $1=$ mild; $2=$ moderate; and $3=$ severe diarrhea), and the degree of blood in the stool was evaluated on a scale from 0 to 2 ( 0 = negative; $1=$ hemoccult positive; and 2 = gross bleeding).

Twenty-one experimental days after intracolonic TNBS instillation, the animals of each group were sacrificed by cervical dislocation under deep ether anesthesia.

In performing the protocol, the authors adhered to the Israel National Research Council criteria for the care and use of laboratory animals.

\section{Experimental design}

The following groups of rats were included in the present study: control (no treatment $[\mathrm{n}=10])$; TNBS treated (TNBS + vehicle $[\mathrm{n}=10]$ ); and TNBS + losartan treated $(\mathrm{n}=10)$. Losartan or vehicle were administered by oral gavage using a $5 \mathrm{~cm}$ catheter $(7 \mathrm{mg} / \mathrm{kg} /$ day in $2.5 \mathrm{~mL}$ of saline, or $2.5 \mathrm{~mL}$ saline only, respectively), with daily administration starting on day 0 and continued for 21 days.

\section{Sample recovery and preparation}

Under ether anesthesia, a laparotomy was performed, the colon was visualized and rapidly excised in its entirety and placed in a petridish 
containing sterile saline solution. The presence of adhesions between the colon and the adjacent organs was scored on a scale from 0 to 3 ( 0 $=$ absent $; 1=\operatorname{mild} /$ focal; 2 = moderate $/$ zonal; and $3=$ severe $/$ diffuse $)$ (56). The colon was opened longitudinally, rinsed with sterile saline, weighed, measured and subsequently attached to a wooden tongue depressor for the assessment of macroscopic lesions. It was subsequently cut longitudinally to obtain two equivalent strips. One of the colonic strips was fixed in $4 \%$ buffered formaldehyde and embedded in paraffin for histological studies. Sections were cut to a thickness of $5 \mu \mathrm{m}$ and stained with hematoxylin and eosin (H\&E) and Sirius red. The other colonic strip was stored at $-80^{\circ} \mathrm{C}$ for determination of TGF- $\beta 1$ levels at a later time.

\section{Assessment of macroscopic and microscopic colonic lesions}

Two independent observers (GZ and OP), who were blinded to the treatment groups, assessed and scored the individual macroscopic colonic lesions accrding to the following 0 to 3 scale: colon thickness $(0=$ normal; 1 = mild increase; $2=$ moderate increase; and $3=$ marked increased $)$, mucosal edema/hyperemia $(0=$ absent; $1=$ mild; 2 = moderate; and 3 = severe $) ;$ mucosal ulcers $(0=$ absent; 1 = single ulceration; 2 = ulcerations at one site; and $3=$ ulcerations at more sites); and extension of the mucosal lesions (percentage of damaged mucosal surface) (56). The sum of the scores assessing colonic lesions, including adhesions, thickness, edema/hyperemia and ulcers, was expressed as a total macroscopic score.

Large bowel specimens obtained from all animals were washed and immediately immersed in $10 \%$ buffered formalin in phosphate-buffered saline $(\mathrm{pH} \mathrm{7.4)}$ for $3 \mathrm{~h}$ at room temperature followed by the standard procedure for paraffin embedding. Serial $3 \mu \mathrm{m}$ sections were stained with $H \& E$ to assess the degree of inflammation, and with Sirius red to detect connective tissue and fibrosis. The stained sections were then observed under a light microscope (Olympus BX51 [Olympus Optical Co Ltd, Japan]). Two blinded pathologists (GZ and OP) examined and scored all histological sections of colonic samples according to the presence of ulcerations, degree of inflammation, depth of the lesions and fibrosis $(56,57)$. The total microscopic score was obtained by adding the subscores of change in all of the different histological parameters.

The degree of intestinal inflammation was scored as absent, mild, moderate or severe, according to the density and extent of both the acute and chronic inflammatory infiltrate, loss of goblet cells and bowel wall thickening (57). Intestinal fibrosis was scored as mild, moderate or severe, according to the density and extent of Sirius redpositive connective tissue staining and disruption of tissue architecture, compared with the control rats, according to a method previously described $(56,57)$. In this method, the severity of increased connective tissue deposition is assigned a score of 0 (normal) to 3 (the most severe fibrosis, representing progressive increased collagen deposition throughout all layers from mucosa to serosa).

\section{Measurement of colonic mucosal TGF- $\beta 1$ levels}

Determination of TGF- $\beta 1$ levels was performed using ELISA (27). Briefly, tissue was homogenized in the presence of a mixture of protease inhibitors (for the inhibition of serine, cysteine, aspartic proteases and aminopeptidases $[1 \mathrm{~mL} / 20 \mathrm{~g}]$ ) to improve the yield of fully functional proteins. The tissue homogenate was centrifuged at $1600 \mathrm{~g}$ at $0^{\circ} \mathrm{C}$ for $15 \mathrm{~min}$, and the supernatant was transferred to a microfuge tube on ice. The supernatants were purified in $1 \%$ trifluoroacetic acid, centrifuged at $17,000 \mathrm{~g}$ for $20 \mathrm{~min}$ at $4^{\circ} \mathrm{C}$, and eluted through a $\mathrm{C} 18$ column (Rik-Sepcol [Peninsula Laboratories, USA]) with 100\% acetonitrile (Baker, USA) + 1\% trifluoroacetic acid. For determination of TGF- $\beta 1$ levels, an aliquot of the supernatents was treated with $1 \mathrm{~N}$ $\mathrm{HCl}$ to activate TGF- $\beta 1$, followed by neutralization with $1 \mathrm{~N} \mathrm{NaOH}$, and a standard ELISA assay was performed (Quantikine [R\&D Systems, USA]).
TABLE 1

Effects of losartan administration on the course and macroscopic findings of colitis in rats

\begin{tabular}{lccc}
\hline & $\begin{array}{c}\text { Control } \\
\text { Parameters }\end{array}$ & \multicolumn{2}{c}{ Trinitrobenzene sulphonic acid } \\
\cline { 3 - 4 } Mortality, $\mathrm{n}$ & 0 & $\mathbf{+}$ Vehicle $(\mathrm{n}=10)$ & + Losartan $(\mathrm{n}=10)$ \\
Body weight, $\mathrm{g}$ & $296.50 \pm 12.48$ & $244.43 \pm 11.44$ & 1 \\
Colon weight, $\mathrm{g}$ & $0.43 \pm 0.04$ & $1.33 \pm 0.24$ & $0.68 \pm 0.14^{*}$ \\
Colon length, $\mathrm{cm}$ & $15.76 \pm 0.55$ & $9.96 \pm 0.33$ & $12.77 \pm 0.84^{*}$ \\
Adhesions & 0 & $2.43 \pm 0.79$ & $1.00 \pm 0.87^{\dagger}$ \\
Thickness & 0 & $1.86 \pm 1.07$ & $0.56 \pm 0.53^{\dagger}$ \\
Mucosal edema/ & 0 & $1.57 \pm 0.79$ & $0.89 \pm 0.60$ \\
$\quad$ hyperemia & 0 & & \\
Mucosal ulcers & 0 & $0.86 \pm 0.69$ & $0.33 \pm 0.50$ \\
Damage, \% & 0 & $37.14 \pm 20.80$ & $12.22 \pm 10.03^{\dagger}$ \\
Diarrhea & 0 & $2.43 \pm 0.79$ & $0.56 \pm 0.73^{\dagger}$ \\
Hematochezia & $0.71 \pm 49$ & $0.11 \pm 0.33^{\dagger}$ \\
\hline
\end{tabular}

Data presented as mean $\pm S D$ unless otherwise indicated. ${ }^{*} P \leq 0.05$ by honest significant difference Tukey's test after one way parametric ANOVA; ${ }^{\dagger} P \leq 0.017$ by Wilcoxon rank-sum test after Kruskal-Wallis nonparametric ANOVA

\section{Statistical analysis}

Data are reported as mean \pm SD. For ordinal variables (colorectal adhesions, thickness, mucosal edema/hyperemia, mucosal ulcers and extent of damage, total macroscopic and microscopic scores, degree of fibrosis, as well as diarrhea and hematochezia), results in all groups of rats were analyzed using Kruskal-Wallis nonparametric ANOVA. Post hoc comparisons between pairs of groups were assessed using the Wilcoxon rank-sum test, with a downward adjustment of the $\alpha$ level to compensate for multiple comparisons. To maintain the overall probability at a level of 0.05 in the three independent comparisons, the $\alpha$ value was divided by 3 to obtain a comparison wise $\alpha=0.017$ (ie, $0.05 / 3)$; thus, each comparison was significant at the 0.017 level.

For quantitative variables (body weight, colorectal weight, length and TGF- $\beta 1$ levels), results in all groups of rats were analyzed using one-way parametric ANOVA. Post hoc comparisons between pairs of groups were assessed using the honest significant differenceTukey's test, with $\mathrm{P}<0.05$ considered to be statistically significant.

Data analysis was performed using SAS version 9.2 (SAS Institute, Inc, USA).

\section{RESULTS}

Clinical and macroscopic findings of colitis

The effects of losartan administration on the course and macroscopic findings of TNBS-induced colitis in rats are summarized in Table 1.

On day 21 after TNBS administration, patchy mild/moderate mucosal lesions were observed. However, all rats presented macroscopically visible strictures of the distal colon with proximal dilation, and the colon length was much shorter. The mortality rate of rats in the TNBS and TNBS + losartan groups was three in 10 (30\%), and one in $10(10 \%)$, respectively. Losartan administration resulted in a significant improvement in colon weight, length, adhesions, thickness, mucosal edema/hyperemia, ulcerations, and extent of damage. Furthermore, losartan administration improved the macroscopic severity of fibrosis of the colonic wall. The total macroscopic colonic damage score was significantly lower in the TNBS + losartan-treated rats compared with TNBS rats receiving only the vehicle (Figure 1A).

In a group of six rats receiving TNBS without vehicle, clinical, macroscopic and microscopic findings, similar to those observed in mice with TNBS plus vehicle, were found (data not shown).

\section{Microscopic findings}

A representative microscopic histology panel (H\&E and Sirius red staining) of the colon from control, TNBS-treated and TNBS + losartan-treated rats is shown in Figure 2. 


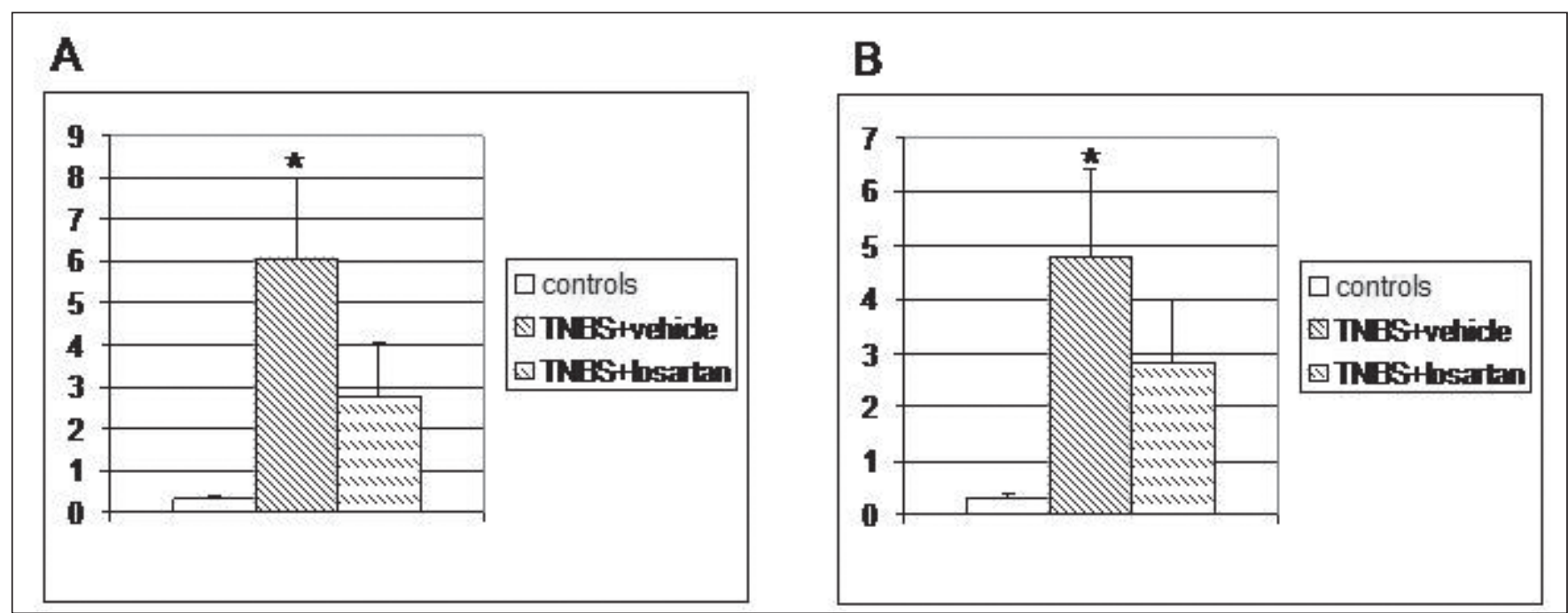

Figure 1) A Total macroscopic colonic damage score at day 21 in control, trinitrobenzene sulphonic acid (TNBS) + vehicle- and TNBS + losartan-treated rats. Values are expressed as mean $\pm S D$. $* P<0.017$ versus controls and TNBS + vehicle, by Wilcoxon rank-sum test after Kruskal-Wallis nonparametric ANOVA. B Total microscopic colonic damage score at day 21 in control, TNBS + vehicle and TNBS + losartan-treated rats. Values are expressed as mean \pm SD. $* P<0.017$ versus controls and TNBS + vehicle, by Wilcoxon rank-sum test after Kruskal-Wallis nonparametric ANOVA

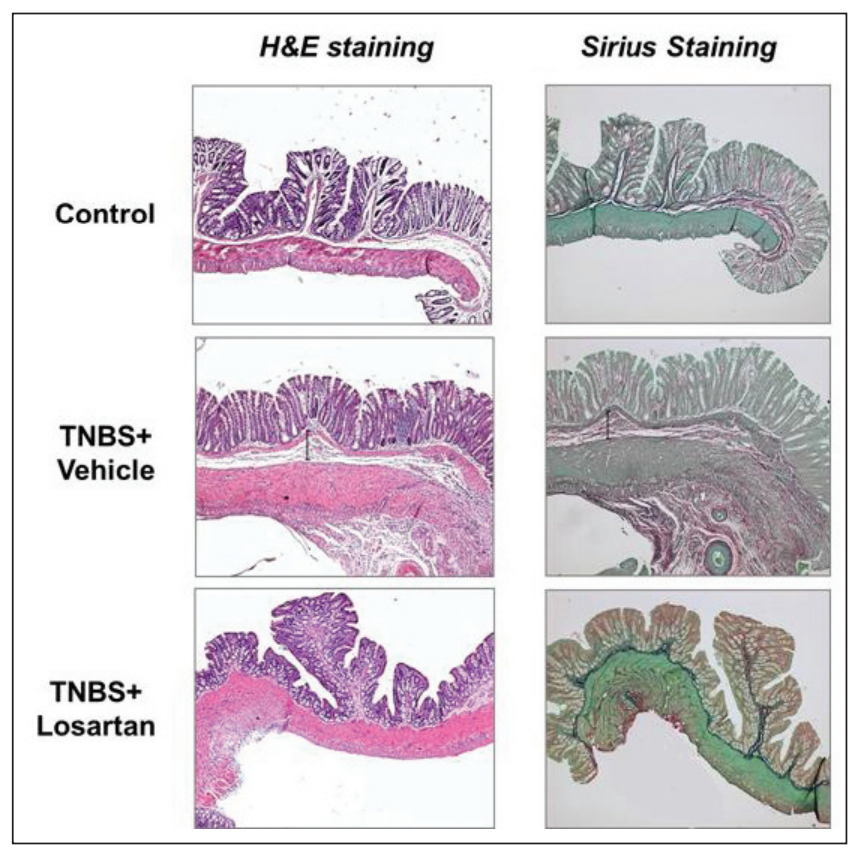

Figure 2) Representative microscopic histology (hematoxylin and eosin [HEE], and Sirius red staining) of the colon from control, trinitrobenzene sulphonic acid (TNBS) + vehicle- and TNBS + losartan-treated rats at day 21. HEE staining of the colon shows a normal colonic mucosa in the control group. In the TNBS + vehicle rats, a dense cellular fibrosis was observed in the colonic submucosa together with regenerative changes in the overlying epithelium. The colon of TNBS + losartan-treated rats shows a normal mucosal architecture and a mild fibrosis in the submucosa. Sirius red staining of the colon shows a marked fibrosis in the TNBS + vehicle-treated rats, a mild fibrosis in the TNBS + losartan-treated rats, and a normal finding in the control rats

In the TNBS-treated rats, the affected colonic wall consisted of granulomatous tissue in which fibroblasts and fibrosis were seen in the submucosa together with regenerative changes in the overlying epithelium. The colon of the TNBS + losartan-treated rats showed nearly normal mucosal architecture and minimal granulation tissue and fibrosis in the submucosa (Figure 2). The degree of colonic fibrosis was significantly lower in the TNBS + losartan-treated rats

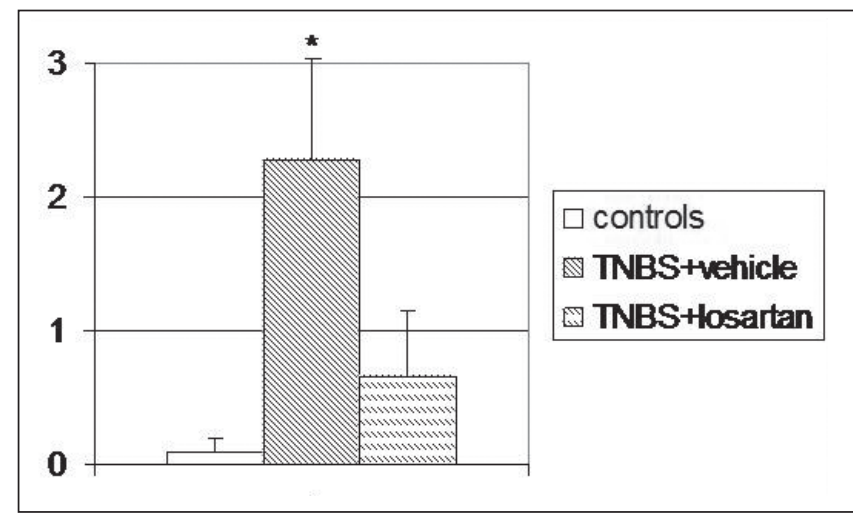

Figure 3) Degree of colonic fibrosis in control, trinitrobenzene sulphonic acid (TNBS)-treated and TNBS + losartan-treated rats. Values are expressed as mean $\pm S D . * P<0.017$ versus controls and TNBS + vehicle, by Wilcoxon rank-sum test after Kruskal-Wallis nonparametric ANOVA

compared with untreated TNBS rats $(2.28 \pm 0.75$ versus $0.66 \pm 0.50$, respectively $[\mathrm{P}<0.017])$ (Figure 3$)$. The total microscopic score was lower in the TNBS + losartan-treated group compared with the TNBS-treated group (Figure 1B).

Colonic TGF- $\beta 1$ levels

TNBS-treated rats had significantly higher tissue concentrations of TGF- $\beta 1$ compared with control rats $(1389.60 \pm 697.83 \mathrm{pg} / \mathrm{mL}$ versus $147.60 \pm 63.21 \mathrm{pg} / \mathrm{mL}$, respectively $[\mathrm{P}<0.05])$. Losartan administration in TNBS rats significantly lowered TGF- $\beta 1$ levels when compared with TNBS alone $(173.72 \pm 122.18 \mathrm{pg} / \mathrm{mL}$ versus $1389.60 \pm 697.83 \mathrm{pg} / \mathrm{mL}$, respectively $[\mathrm{P}<0.05]$ ) (Figure 4$)$.

\section{DISCUSSION}

In IBD, particularly in CD, and in other chronic enteropathies, chronic transmural inflammation triggers the activation of fibrogenetic mesenchymal cells, which leads to abnormal local deposition of ECM proteins, including collagen, and then to fibrosis and strictures $(4,5)$. Despite recent advances in IBD therapy, the development of intestinal fibrosis and strictures remains a challenging complication of these diseases, particularly in CD (5). Existing therapies, predominantly aminosalicylates, steroids, immunomodulators and, more recently, biological therapies, can relieve the inflammatory symptoms 
of the intestinal fibrostenotic diseases such as CD, but they do not significantly improve stricture lesions of the bowel $(2,3)$. Therefore, intestinal fibrosis and its associated complications remain the major causes of surgical intervention for which there are no approved pharmacological approaches.

Fibrosis is a chronic and progressive process mediated by complex cell/ECM/cytokine and growth factor interactions, but it may be a reversible phenomenon - even in advanced stages $(4,5,10-15)$. This has stimulated research on the development of antifibrotic drugs that inhibit the accumulation of activated ECM-producing cells and their profibrogenic actions, or promote ECM degradation. Nevertheless, efficient and well-tolerated antifibrotic drugs are still lacking because the main molecular pathway of fibrogenesis has yet to be elucidated.

In the present study, we showed that the prophylactic oral administration of losartan, an ANGII type 1 receptor antagonist, attenuates the development and progression of colonic fibrosis in TNBS-induced chronic colitis in rats, which appears to be related to the inhibition of the colonic expression of TGF- $\beta 1$. Daily losartan administration for 21 days significantly decreased the macroscopic and microscopic pattern of both colonic inflammation and fibrosis and re-established normal colonic TGF- $\beta 1$ levels. The production of TGF- $\beta 1$ has been shown to be stimulated by the local activation of ANGII, which represents the primary effector molecule of the RAS (32-38). Renin converts ANG into ANGI, and ACEs convert ANGI into ANGII. To date, four ANG receptors, ANG types 1 to 4 (AT1-4), have been identified. AT1 has further been subdivided into AT1a and AT1b. ANGII binds to both AT1 and AT2. AT1 is responsible for most of the physiological and pathophysiological actions of ANGII. ANG receptor blockers, currently used as antihypertensive drugs, are selective AT1 antagonists.

The reported role of RAS, usually regarded as an endocrine system that regulates physiological and vital cardiovascular processes, has expanded in the past decade to include independently regulated local systems in several tissues, new functions and new active products of ANGII $(58,59)$. It has been reported that all components of the RAS exist in the human large bowel (60). In the colon, many cells such as epithelial, vascular endothelial, mesenchymal and inflammatory cells express ANGII receptors. ANGII participates in the pathogenesis of chronic fibrogenetic diseases of several organs, including the intestine, through the regulation of both inflammatory and fibrotic processes $(61,62)$. The direct effect of ANGII on the pathogenesis of immunemediated colitis was assessed using mice genetically deficient in angiotensinogen $\left(\mathrm{Atg}^{-/-}\right)$, which is the precursor of ANGII (63). The degree of TNBS-induced acute colitis was less severe in the $\mathrm{Atg}^{-1-}$ mice than that in wild-type $\left(\mathrm{Atg}^{+/+}\right)$mice. ANGII contributes to the recruitment of infiltrating inflammatory cells into the affected organ by the upregulation of adhesion molecules, chemokines and many proinflammatory cytokines. ACE inhibitors and AT1 receptor antagonists have been shown to diminish inflammatory markers and inflammatory cell infiltration (61-63). Through the AT1 receptor, ANGII promotes ECM accumulation and fibrosis by the local production of profibrotic molecules such as TGF- $\beta$ and CTGF. ACE inhibitors and AT1 antagonists reduce tissue fibrosis and TGF- $\beta$ expression (62). Furthermore, blockade of TGF- $\beta$ decreases ECM production induced by ANGII. We previously reported that prophylactic oral admistration of the ACE inhibitor captopril prevented the development of colorectal fibrosis in TNBSinduced colitis and reduced colorectal TGF- $\beta$ levels (27). The same results have been reported with losartan in the present study. The rescue effects of losartan on established colonic fibrosis was not evaluated; however, the therapeutic antifibrotic effect of losartan on established fibrosis in different organs was previously reported $(41,45,51)$. It is worth noting that the beneficial effect of both captopril and losartan in the prevention of colonic fibrosis occurs with a partial downregulation of TGF- $\beta$, as reported in other organs $(41,42,49)$. Accordingly, blockade of ANGII reduced renal, cardiac and hepatic fibrosis by inhibiting TGF- $\beta$ expression by $40 \%$ to $60 \%$. This finding could be explained by the different role of TGF- $\beta$ in the wound healing response. At low femtomolar concentrations, TGF- $\beta 1$ promotes the healing of acutely damaged

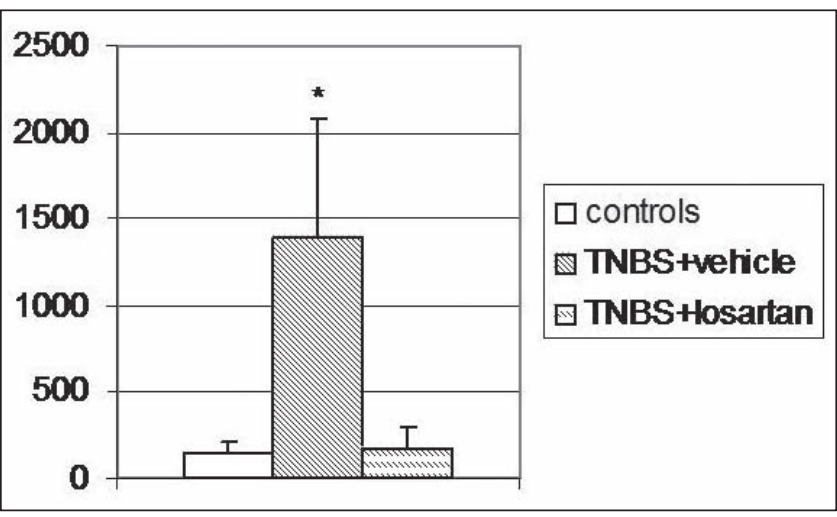

Figure 4) Colonic concentration of transforming growth factor-beta $1(\mathrm{pg} / \mathrm{mL})$ in control, trinitrobenzene sulphonic acid (TNBS) + vehicle- and TNBS + losartan-treated rats. Values are expressed as mean $\pm S D . * P<0.05$ versus controls and TNBS + losartan, by honest significant difference Tukey's test after one way parametric ANOVA

tissue, and fibrosis does not occur. In chronic diseases, repeated injury sustains the overproduction of TGF- $\beta 1$, leading to progressive activation of monocytes that, in turn, release growth factors that stimulate fibroblasts to produce ECM resulting in tissue fibrosis (64). These findings are consistent with the observation that gene transfer of TGF- $\beta 1$ to the mouse colon leads to intestinal fibrosis (28). On the other hand, suppresing excessive TGF- $\beta 1$ bioactivity by using a TGF- $\beta 1$ peptidebased vaccine ameliorates the development of intestinal fibrosis and associated complications in a mouse model of TNBS-induced chronic colitis (65). Nevertheless, although TGF- $\beta$ is one of the main regulators of fibrosis, therapeutic strategies aimed at blocking TGF- $\beta$ have not demonstrated the expected beneficial effects, probably due to its anti-inflammatory actions $(20,66)$. For these reasons, novel antifibrotic targets including Smad proteins and CTGF are under consideration. Smad proteins, which are important components of intracellular signalling pathways, act as transcription factors in the majority of TGF- $\beta$-mediated responses including fibrosis $(17-19,64)$. It has been reported that ANGII, through the AT1 receptor, activates the Smad2 and Smad4 signalling system, and Smad-dependent gene transcription independently of TGF- $\beta$ (62). Smad7 functions as a negative regulator of TGF- $\beta$ receptor signalling. Disruption of the Smad signalling pathway, either through the loss of Smad3 or the increase of Smad7 expression, confers resistance to tissue fibrosis in several organs including skin, kidney, lung and liver (19,67-75). In previous studies, we also recognized the important role of Smad proteins in the development of intestinal fibrosis, and demonstrated that the beneficial effects of antifibrotics is associated with a downregulation of both Smad and CTGF proteins $(56,76)$. CTGF is a pivotal profibrotic factor that is upregulated in the fibrotic process of several organs $(30,31,62)$. CTGF is a potent stimulator of activated myofibroblasts, and ECM production and deposition. ANGII, via AT1, upregulates CTGF production and fibrosis by the activation of the Smad signalling system and the Rho/Rho kinase pathway independendly of TGF- $\beta(62,77)$. ACE inhibitors and AT1 antagonists reduced CTGF expression and fibrosis. Furthemore, blockade of CTGF reduced ANGII-induced fibrosis. Collectively, these data suggest that drugs that inhibit RAS and, in particular, AT1 antagonists such as losartan, could lead to a selective blockade of intracellular fibrogenic TGF- $\beta$-mediated transduction signalling pathways without involving physiologically important - or even vital - TGF- $\beta$ activities. Additional studies are necessary to evaluate their potential therapeutic effects in fibrostenosing chronic enteropathies, particularly CD. The association of the angiotensinogen- 6 variant with CD supports a potential role for ACE inhibitors and ANGII receptor antagonists in the treatment of this disease (78). 


\section{CONCLUSION}

The present study demonstrated that the prophylactic oral administration of losartan, an ANGII receptor antagonist, attenuates colorectal fibrosis in experimental TNBS-induced colitis. This effect of losartan appears to be mediated by a downregulation of TGF- $\beta 1$ expression. An indirect antifibrotic effect of losartan may also persist through its anti-inflammatory action. Thus, losartan may represent an effective prophylactic agent in reducing the risk of intestinal fibrosis and strictures in patients with CD.

IN MEMORIAM: All authors will remember with great esteem and affection Giuliana Zanninelli, who suddenly, and at an early age, departed this world. Giuliana was the most brilliant member of the research group and will be sadly missed by all who knew her.

\section{REFERENCES}

1. Geboes KP, Cabooter L, Geboes K. Contribution of morphology for the comprehension of mechanisms of fibrosis in inflammatory enterocolitis. Acta Gastroenterol Belg 2000;63:371-6.

2. Van Assche G. Can we influence fibrosis in Crohn's disease? Acta Gastroenterol Belg 2001;64:193-6.

3. Van Assche G, Geboes K, Rutgeerts P. Medical therapy for Crohn's disease strictures. Inflamm Bowel Dis 2004;10:55-60.

4. Rieder F, Brenmoehl J, Leeb S, Scholmerich J, Rogler G. Wound healing and fibrosis in intestinal disease. Gut 2007;56:130-9.

5. Burke JP, Mulsow JJ, O'Keane C, Docherty NG, Watson RW, O'Connell PR. Fibrogenesis in Crohn's disease. Am J Gastroenterol 2007;102:439-48.

6. Rutgeerts P. Review article: Recurrence of Crohn's disease after surgery - the need for treatment of new lesions.

Aliment Pharmacol Ther 2006;24 Suppl 3:29-32.

7. Cosnes J, Nion-Larmurier I, Beaugerie L, Afchain P, Tiret E, Gendre JP. Impact of the increasing use of immunosuppressants in Crohn's disease on the need for intestinal surgery.

Gut 2005;54:237-41.

8. Graham MF, Diegelmann RF, Elson CO, et al. Collagen content and types in the intestinal strictures of Crohn's disease. Gastroenterology 1988;94:257-65.

9. Stallmach A, Schuppan D, Riese HH, Matthes H, Riecken EO. Increased collagen type III synthesis by fibroblasts isolated from strictures of patients with Crohn's disease. Gastroenterology 1992;102:1920-1929

10. Powell DW, Mifflin RC, Valentich JD, Crowe SE, Saada JI, West AB. Myofibroblasts I. Paracrine cells important in health and disease. Am J Physiol Cell Physiol 1999;277:C1-19.

11. Powell DW, Mifflin RC, Valentich JD, Crowe SE, Saada JI, West AB. Myofibroblasts II. Intestinal subepithelial myofibroblasts. Am J Physiol Cell Physiol 1999;277:C183-201.

12. Pucilowska JB, Williams KL, Lund PK. Fibrogenesis IV. Fibrosis and inflammatory bowel disease: Cellular mediators and animal models. Am J Physiol Gastrointest Liver Physiol 2000;279:G653-9.

13. Bonniaud P, Margetts PJ, Ask K, Flanders K, Gauldie J, Kolb M. TGF- $\beta$ and Smad 3 signaling link inflammation to chronic fibrogenesis. J Immunol 2005;175:5390-5.

14. Wynn T. Cellular and molecular mechanisms of fibrosis. J Pathol 2008;214:199-210.

15. Desmet VJ, Roskams T. Cirrhosis reversal: A duel between dogma and myth. J Hepatol 2004;40:860-67.

16. McKaig BC, Hughes k, Tighe PJ, Mahida YR. Differential expression of TGF- $\beta$ isoforms by normal and inflammatory bowel disease intestinal myofibroblasts. Am J Physiol Cell Physiol 2002;282:C172-82.

17. Wells RG. Fibrogenesis V. TGF-b signaling pathways. Am J Physiol Gastrointest Liver Physiol 2000;279:G845-50.

18. Derynck R, Zhang YE. Smad-dependent and Smad-independent pathways in TGF- $\beta$ family signalling. Nature 2003;425:577-84.

19. Flanders KC. Smad 3 as a mediator of the fibrotic response. Int J Exp Pathol 2004;85:47-64.

20. Monteleone G, Pallone F, MacDonald TT. Smad7 in TGF- $\beta$ mediated negative regulation of gut inflammation.

Trends Immunol 2004;25:513-7.
21. Fichtner-Feigl S, Fuss IJ, Young CA, et al. Induction of IL-13 triggers TGF- $\beta 1$-dependent tissue fibrosis in chronic 2,4,6-trinitrobenzene sulfonic acid colitis. J Immunol 2007;178:5859-5870

22. Beddy D, Mulsow J, Watson RW, Fitzpatrick JM, O'Connell PR. Expression and regulation of connective tissue growth factor by transforming growth factor beta and tumour necrosis factor alpha in fibroblasts isolated from strictures in patients with Crohn's disease. Br J Surg 2006;93:1290-6.

23. Mulsow JJ, Watson RW, Fitzpatrick JM, O'Connell PR. Transforming growth factor-beta promotes pro-fibrotic behavior by serosal fibroblasts via PKC and ERK1/2 mitogen activated protein kinase cell signaling. Ann Surg 2005;242:880-7.

24. Lawrance IC, Maxwell L, Doe W. Altered response of intestinal mucosal fibroblasts to profibrogenic cytokines in inflammatory bowel disease. Inflamm Bowel Dis 2001;7:226-36.

25. Di Mola F, Friess H, Scheuren A, et al. Transforming growth factor- $\beta$ s and their signaling receptors are co expressed in Crohn's disease. Ann Surg 1999;229:67-75.

26. Mourelle M, Salas A, Guarner F, Crespo E, Garcia-Lafuente A, Malagelada JR. Stimulation of transforming growth factor beta- 1 by enteric bacteria in the pathogenesis of rat intestinal fibrosis. Gastroenterology 1998;114:519-26.

27. Wengrower D, Zanninelli G, Pappo O, et al. Prevention of fibrosis in experimental colitis by captopril: The role of TGF- $\beta 1$. Inflamm Bowel Dis 2004;10:536-45.

28. Vallance BA, Gunawan MI, Hewlett B, et al. TGF-betal gene transfer to the mouse colon leads to intestinal fibrosis. Am J Physiol Gastrointest Liver Physiol 2005;116-G128.

29. McKaig BC, McWilliams D, Watson SA, Mahida YR. Expression and regulation of tissue inhibitor of metalloproteinase- 1 and matrix metalloproteinases by intestinal myofibroblasts in inflammatory bowel disease. Am J Pathol 2003;162:1355-60.

30. Dammeier J, Brauchle M, Falk W, Grotendorst GR, Werner S. Connective tissue growth factor: A novel regulator of mucosal repair and fibrosis in inflammatory bowel disease? Int J Biochem Cell Biol 1998;30:909-22.

31. Di Mola FF, Di Sebastiano P, Gardini A, et al. Differential expression of connective tissue growth factor in inflammatory bowel disease. Digestion 2004;69:245-53.

32. Campbell SE, Katwa LC. Angiotensin II stimulated expression of transforming growth factor-betal in cardiac fibroblasts and myofibroblasts. J Mol Cell Cardiol 1997;29:1947-58.

33. Fukuda N, Hu WY, Kubo A, et al. Angiotensin II upregulates transforming growth factor-beta I receptor on rat vascular smooth muscle cells. Am J Hypertens 2000;13:191-8.

34. Schultz Jel J, Witt SA, Glascock BJ, et al. TGF-betal mediates the hypertrophic cardiomyocyte growth induced by angiotensin II. J Clin Invest 2002;109:787-96.

35. Sun Y, Zhang J, Zhang JQ, Ramires FJ. Local angiotensin II and transforming growth factor-betal in renal fibrosis of rats. Hypertension 2000;35:1078-84.

36. Uhal BD, Kim JK, Li X, Molina-Molina M. Angiotensin-TGF-beta1 crosstalk in human idiopathic pulmonary fibrosis: Autocrine mechanisms in myofibroblasts and macrophages. Curr Pharm Des 2007;13:1247-56.

37. Warner FJ, Lubel JS, McCaughan GW, Angus PW. Liver fibrosis: A balance of ACEs? Clin Sci (Lond) 2007;113:109-18.

38. Ruiz-Ortega M, Rodriguez-Vita J, Sanchez-Lopez E, Carvajal G, Egido J. TGF-beta signaling in vascular fibrosis. Cardiovasc Res 2007;74:196-206.

39. Jaszewski R, Tolia V, Ehrinpreis MN, et al. Increased colonic mucosal angiotensin I and II concentration in Crohn's colitis. Gastroenterology 1990;98:1543-8.

40. Tzanidis A, Lim S, Hannan RD, See F, Ugoni AM, Krum H. Combined angiotensin and endothelin receptor blockade attenuate adverse cardiac remodeling post-myocardial infarction in the rat: Possible role of transforming growth factor beta1. J Mol Cell Cardiol 2001;35:969-81.

41. Lim DS, Lutucuta S, Bachireddy P, et al. Angiotensin II blockade reverse myocardial fibrosis in a transgenic mouse model of human hypertrophic cardiomyopathy. Circulation 2001;103:789-91.

42. Agarwal R, Siva S, Dunn SR, Sharma K. Add-on angiotensin II receptor blockade lowers urinary transforming growth factor-beta levels. Am J Kidney Dis 2002;39:486-92. 
43. Ishikawa A, Tanaka M, Ohta N, Ozono S, Kitamura T. Prevention of intestitial fibrosis of renal allograft by angiotensin II blockade. Transplant Proc 2006;38:3498-501.

44. Kellner D, Chen J, Richardson I, et al. Angiotensin receptor blockade decreases fibrosis and fibroblast expression in a rat model of unilateral ureteral obstruction. J Urol 2006;176:806-12.

45. Boffa JJ, Lu Y, Placier S, Stefanski A, Dussaule JC, Chatziantoniou C. Regression of renal vascular and glomerular fibrosis: Role of angiotensin II receptor antagonism and matrix metalloproteinases. J Am Soc Nephrol 2003;14:1132-44.

46. Königshoff M, Wilhelm A, Jahn A, et al. The angiotensin II receptor 2 is expressed and mediates angiotensin II signaling in lung fibrosis. Am J Respir Cell Mol Biol 2007;37:640-50.

47. Yao HW, Zhu JP, Zhao MH, Lu Y. Losartan attenuates bleomycin-induced pulmonary fibrosis in rats. Respiration 2006;73:236-42.

48. Yoshiji H, Kuriyama S, Yoshiji J, et al. Angiotensin II type 1 receptor interaction is a major regulator for liver fibrosis development in rats. Hepatology 2001;34:745-50.

49. Jonsson JR, Clouston AD, Ando Y, et al. Angiotensin-converting enzyme inhibition attenuates the progression of rat hepatic fibrosis. Gastroenterology 2001;121:148-55.

50. Ibañez P, Solis N, Pizarro M, et al. Effect of losartan on early liver fibrosis development in a rat model of nonalcoholic steatohepatitis. J Gastroenterol Hepatol 2007;22:846-51.

51. Sookoian S, Fernández MA, Castaño G. Effects of six months losartan administration on liver fibrosis in chronic hepatitis $\mathrm{C}$ patients: A pilot study. World J Gastroenterol 2005;11:7560-3.

52. El-Demerdash E, Salam OM, El-Batran SA, Abdallah HM, Shaffie NM. Inhibition of the renin-angiotensin system attenuates the development of liver fibrosis and oxidative stress in rats. Clin Exp Pharmacol Physiol 2008;35:159-67.

53. Wang XP, Zhang R, Wu K, Wu L, Dong Y. Angiotensin II mediates acinar cell apoptosis during the development of rat pancreatic fibrosis by AT1R. Pancreas 2004;29:264-70.

54. Liu WB, Wang XP, Wu K, Zhang RL. Effects of angiotensin II receptor antagonist, losartan on the apoptosis, proliferation and migration of the human pancreatic stellate cells. World J Gastroenterol 2005;11:6489-94.

55. Morris GP, Beck PL, Herridege MS, Depew WT, Szewezuk MR, Wallace JL. Hapten-induced model of chronic inflammation and ulceration in the rat colon. Gastroenterology 1989;96:795-803.

56. Latella G, Sferra R, Vetuschi A, et al. Prevention of colonic fibrosis by Boswellia and Scutellaria extracts in rats with colitis induced by 2,4,5-trinitrobenzene sulphonic acid. Eur J Clin Invest 2008;38:410-20.

57. Lawrance IC, Wu F, Leite AZA, et al. A murine model of chronic inflammation-induced intestinal fibrosis down-regulated by antisense NF-kB. Gastroenterology 2003;125:1750-61.

58. Mehta PK, Griendling KK. Angiotensin II cell signaling: Physiological and pathological effects in the cardiovascular system. Am J Physiol Cell Physiol 2007;292:C82-97.

59. Kumar R, Singh VP, Baker KM. The intracellular rennin-angiotensin system: Implications in cardiovascular remodeling. Curr Opin Nephrol Hypertens 2008;17:168-73.

60. Hirasawa K, Sato Y, Hosoda Y, Yamamoto T, Hanai H. Immunohistochemical localization of angiotensin II receptor and local renin-angiotensin system in human colonic mucosa. J Histochem Cytochem 2002;50:275-82.

61. Sironi L, Nobili E, Giannella A, Gelosa P, Tremoli E. Anti-inflammatory properties of drugs acting on the renin-angiotensin system. Drugs Today 2005;41:609-22.

62. Ruiz-Ortega M, Ruperez M, Esteban VL,et al. Angiotensin II: A key factor in the inflammatory and fibrotic response in kidney diseases. Nephrol Dial Transpl 2006;21:16-20.

63. Inokuchi Y, Morohashi T, Kawana I, Nagashima Y, Kihara M, Umemura S. Amelioration of 2,4,6-trinitrobenzene sulphonic acid induced colitis in angiotensinogen gene knockout mice. Gut 2005;54:349-56.

64. Roberts AB, Russo A, Felici A, Flanders KC. Smad3: A key player in pathogenetic mechanisms dependent on TGF-beta. Ann NY Acad Sci 2003;995:1-10.

65. Ma Y, Guan Q, Bai A, et al. Targeting TGF-betal by employing a vaccine ameliorates fibrosis in a mouse model of chronic colitis. Inflamm Bowel Dis 2010;16:1040-50.

66. Grainger DJ. Transforming growth factor beta and atherosclerosis: So far, so good for the protective cytokine hypothesis. Arterioscler Thromb Vasc Biol 2004;24:399-404.

67. Lakos G, Tacagawa S, Chen SJ, et al. Targeted disruption of TGF-beta/Smad3 signaling modulates skin fibrosis in a mouse model of scleroderma. Am J Pathol 2004;165:203-17.

68. Zhao J, Shi W, Wang YL, et al. Smad3 deficiency attenuates bleomycin-induced pulmonary fibrosis in mice. Am J Physiol Lung Cell Mol Physiol 2002;282:L585-93.

69. Schnabl B, Kweon YO, Frederick JP, Wang XF, Rippe RA, Brenner DA. The role of Smad3 in mediating mouse hepatic stellate cell activation. Hepatology 2001;34:89-100.

70. Inazaki K, Kanamaru Y, Kojima Y, et al. Smad3 deficiency attenuates renal fibrosis, inflammation, and apoptosis after unilateral ureteral obstruction. Kidney Int 2004;66:597-604.

71. Fukasawa H, Yamamoto T, Togawa A, et al. Down-regulation of Smad7 expression by ubiquitin-dependent degradation contributes to renal fibrosis in obstructive nephropathy in mice. Proc Natl Acad Sci USA 2004;101:8687-92.

72. Dooley S, Hamzavi J, Breitkopf K, et al. Smad7 prevents activation of hepatic stellate cells and liver fibrosis in rats. Gastroenterology 2003;125:178-91.

73. Dong C, Zhu S, Wang T, et al. Deficient Smad7 expression: A putative molecular defect in scleroderma. Proc Natl Acad Sci USA 2002;99:3908-13

74. Nakao A, Fujii M, Matsumura R, et al. Transient gene transfer and expression of Smad7 prevents bleomycin-induced lung fibrosis in mice. J Clin Invest 1999;104:5-11.

75. Wang B, Omar A, Angelovska T, et al. Regulation of collagen synthesis by inhibitory Smad7 in cardiac myofibroblasts. Am J Heart Cir Physiol 2007;293:H1282-90.

76. Latella G, Vetuschi A, Sferra R, et al. Smad3 loss confers resistance to the development of TNBS-induced colorectal fibrosis. Eur J Clin Invest 2009;39:145-56.

77. Daniel C. Blocking of angiotensin II is more than blocking of transforming growth factor-beta. Kidney Int 2008;74:551-3.

78. Hume GE, Fowler Ev, Lincoln D, et al. Angiotensinogen and transforming growth factor beta1: Novel genes in the pathogenesis of Crohn's disease. J Med Genet 2006;43:e51. 


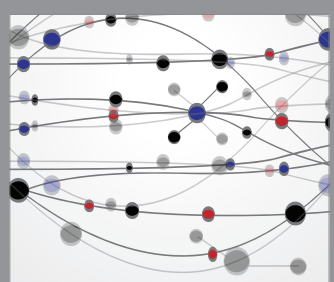

The Scientific World Journal
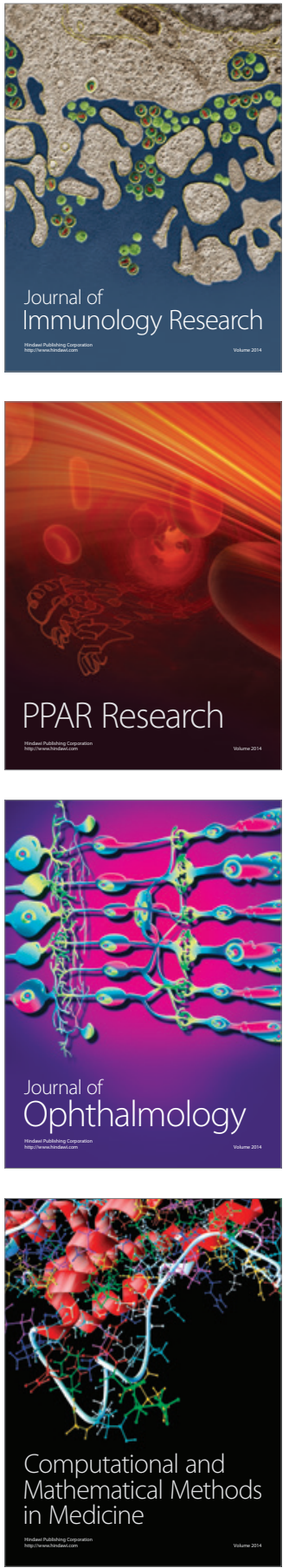

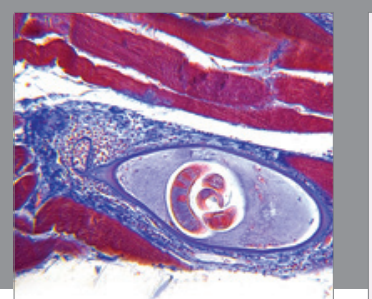

Gastroenterology Research and Practice

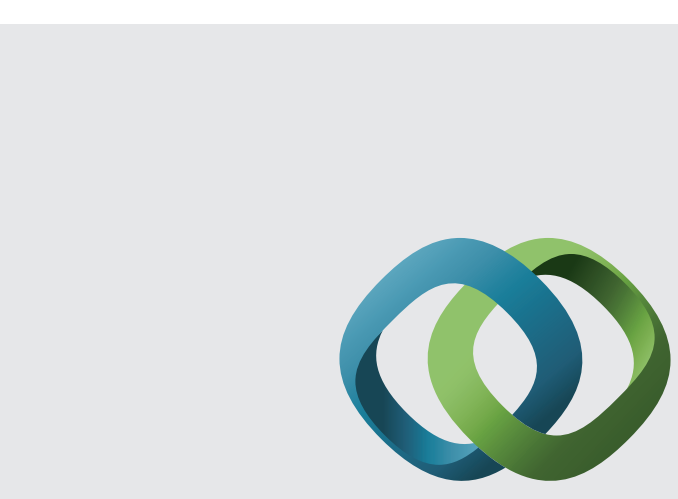

\section{Hindawi}

Submit your manuscripts at

http://www.hindawi.com
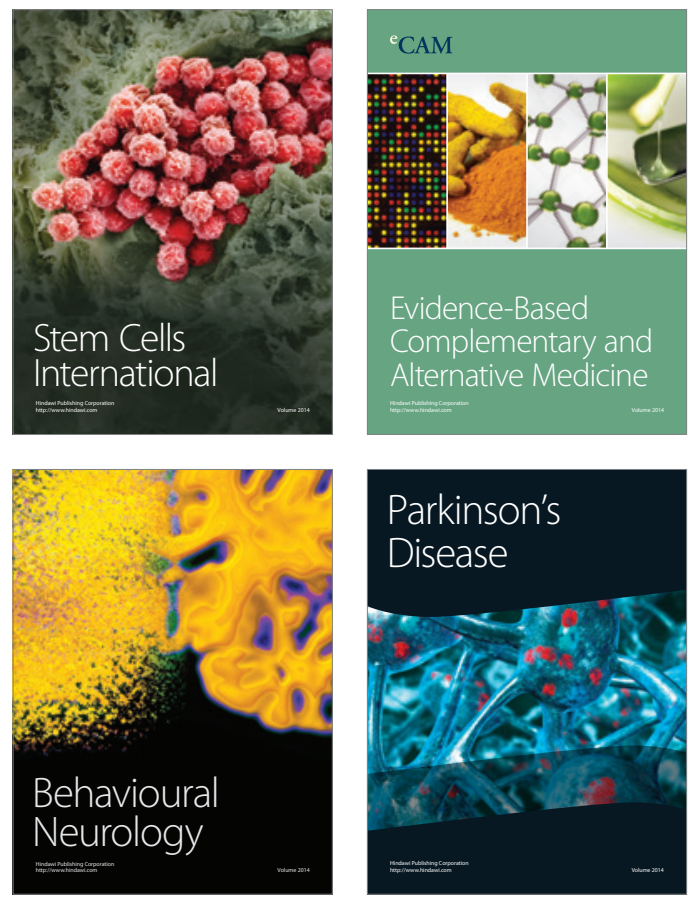
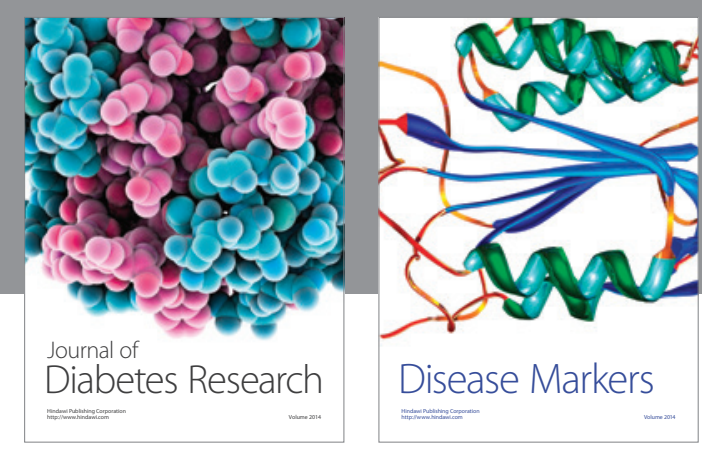

Disease Markers
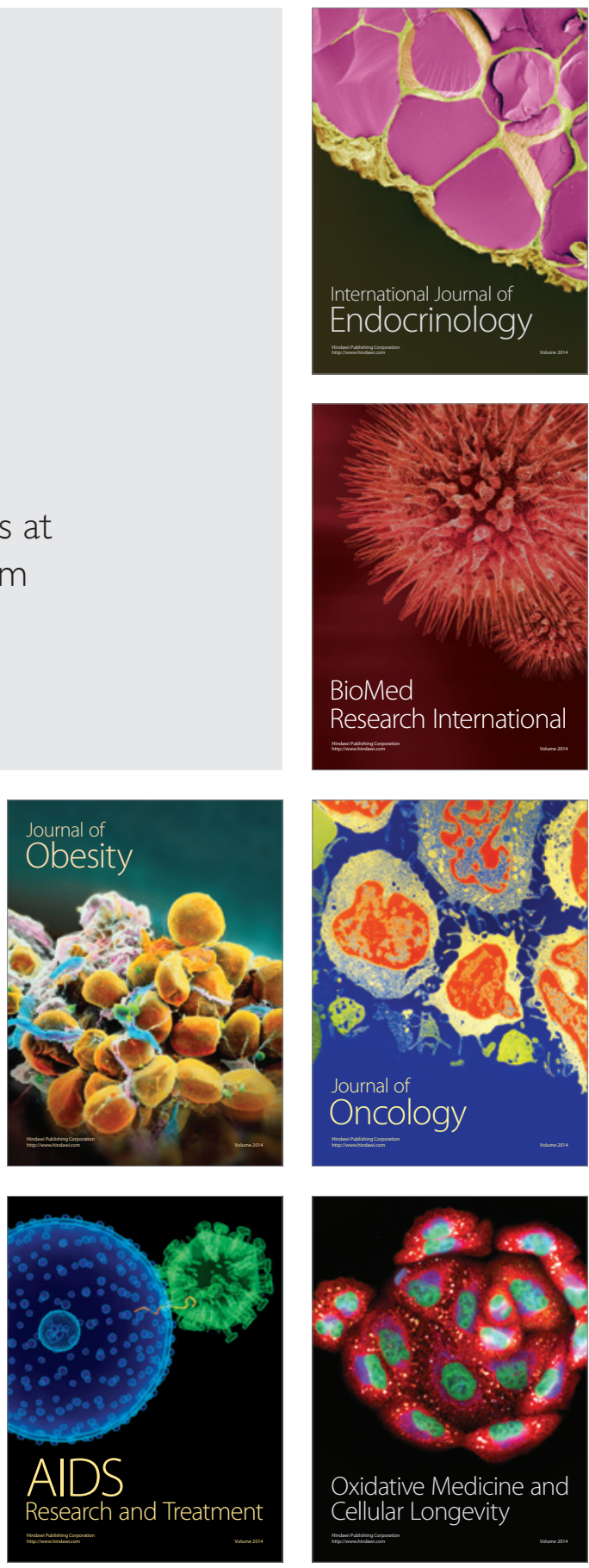